NBER WORKING PAPER SERIES

\title{
A CHILD SUPPORT FRAMEWORK ACCOUNTING FOR PARENTING TIME AND HALF-SIBLINGS
}

\author{
Martin Kulldorff \\ Jay Bhattacharya \\ Working Paper 29411 \\ http://www.nber.org/papers/w29411
NATIONAL BUREAU OF ECONOMIC RESEARCH
1050 Massachusetts Avenue
Cambridge, MA 02138
October 2021

We have no funding source supporting our work on this paper and have no other conflicts of interest to report. The views expressed herein are those of the authors and do not necessarily reflect the views of the National Bureau of Economic Research.

NBER working papers are circulated for discussion and comment purposes. They have not been peer-reviewed or been subject to the review by the NBER Board of Directors that accompanies official NBER publications.

(C) 2021 by Martin Kulldorff and Jay Bhattacharya. All rights reserved. Short sections of text, not to exceed two paragraphs, may be quoted without explicit permission provided that full credit, including $\odot$ notice, is given to the source. 
A Child Support Framework Accounting for Parenting Time and Half-Siblings

Martin Kulldorff and Jay Bhattacharya

NBER Working Paper No. 29411

October 2021

JEL No. I1,I18,J12,J13,K15,K36

\begin{abstract}
$\underline{\text { ABSTRACT }}$
In the United States, child support guidelines sometimes generate surprising and presumably unintentional child support amounts, especially in situations with extended visitation, shared parenting, and half-siblings. These are consequences of the ad-hoc mathematical formulas that are in common use to account for such situations. This paper provides ten such surprising examples from ten randomly selected states.

A child support calculation framework is constructed that takes as inputs the subjective/normative decisions that the public and legislators must make regarding children's expenditures, the progressivity of the contributions between parents, and other matters. Our goal is to derive mathematical formulas for child support amounts that achieve those normative goals while satisfying basic desiderata such as supporting children in both of their families, equity between siblings, neutral medical decisions, and not requiring higher contributions from parents with a lower salary.
\end{abstract}

\author{
Martin Kulldorff \\ Division of Pharmacoepidemiology \\ and Pharmacoeconomics \\ Department of Medicine \\ Harvard University
}

1620 Tremont St. Ste 3030

Boston, MA 02120

martin.kulldorff@gmail.com

Jay Bhattacharya

117 Encina Commons

CHP/PCOR

Stanford University

Stanford, CA 94305-6019

and NBER

jay@stanford.edu 


\section{Introduction}

In the United States, there are 22 million children whose parents live apart [1]. Child support ensures that these children are not deprived of adequate financial resources within the means of the parents. Mandated by the federal government, every state has developed child support guidelines; court mediators and judges alike follow these guidelines to determine a suitable amount of child support [2]. Parents may - and often do - ignore the guidelines by mutual consent [3], but judges are required to follow the guidelines and may only diverge if justified by a written opinion [2, 4]. Other countries have similar systems [5].

We randomly selected ten states. Our analysis of each state's guidelines found multiple design features that generate surprising and presumably unintended child support amounts. The results are due to the mathematical formulas used to account for parenting time, shared parenting, non-joint children, and health insurance, rather than the goals legislators and regulators articulate about child support guidelines.

The designs can generate child support amounts that may be too low or too high relative to amounts that would pertain if the formulas were specified in a way that satisfies a number of axioms we outline. Most children spend some time with both parents, so just as too little child support deprives the children when living with the recipient parent, too much child support can deprive them when living with the paying parent. Too much child support for one child can also reduce the support available for half-siblings.

Children are not the only ones affected by these guidelines. Courts sometimes order parents to pay more child support than they possibly can, and consequently, those parents fail to pay. In the United States, there is $\$ 118$ billion in outstanding child support debt [6], a primary reason being the inability to pay [2, $4,7,8,9]$. Such debt may lead to parental depression, suicidal ideation, and alcohol abuse [10, 11], as well as less parental involvement and deteriorating behavior and socioemotional wellbeing of their children $[12,13]$. When unable to pay, some parents lose their driver's license $[2,4]$ while others are incarcerated $[2,8,9,14,15]$. In a national cohort of urban families, $30 \%$ of non-custodial fathers had child support debt, and $14 \%$ of those incarcerated for non-payment [8]. Some mothers and custodial parents are also sentenced to jail [16].

In effect, states use guidelines to set child support amounts that some parents cannot pay and then jail them when they fail to pay, removing them from the lives of children who love and need them. In a stark assessment, the former commissioner for the U.S. office of child support enforcement, Vickie Turetsky, said 'Unrealistic child support policies and practices entangle poor African American men and their families in poverty and have become a destabilizing force... Child support orders set beyond the ability of noncustodial parents to comply push them out of low-wage jobs, drown them in debt, hound them into the underground economy, and chase them out of their children's lives.' [4] Although also affected by the same guideline design issues, middle-class parents may manage to feed their children and avoid jail by borrowing against housing equity or drawing from retirement savings, college funds, family donations, or business assets.

Current child support formulas generate court litigation, which reduces funds available for the children. This is contrary to the purpose of child support, and it burdens taxpayers who pay for judges and court operations. Health deterioration, debt collection, and incarceration are also costly for taxpayers [2].

Most research on child support has focused on estimating and assigning child-rearing expenditures $[2,17$, 18]. While important, that is not what causes the presumably unintended results in the examples below. 
Surprisingly, a logical and internally consistent framework for dividing parental contributions and allocations under different parenting and family scenarios such as shared parenting and non-joint children does not exist [19]. Instead, states use a hodge-podge of ad hoc mathematical formula adjustments for such situations, resulting in complex child support guidelines with internal inconsistencies and unintended consequences.

In this paper, we construct a foundational framework for child support determination. The framework takes as given subjective norms that the public and legislators must decide regarding typical child expenditures, the progressivity of parental contributions, the allocation between parents, and other matters. Our goal is to derive mathematical formulas that satisfy such norms under different parenting schedules and in the presence of half-siblings.

\section{Examples of Surprising Child Support Outcomes}

We randomly selected ten states and the guidelines they used in 2020. We use each state to illustrate a surprising and presumably unintended child support amount, all of them due to a different design issue in the guideline. In each example, the incomes are hypothetical, while the child support amounts are derived from the state guidelines. Since all guidelines are gender-neutral, the mother/father designation can be reversed without affecting the results. All numbers are annual.

Connecticut: A mother and father with two children have 50/50 equal shared parenting and $\$ 30,000$ and $\$ 42,000$ in net income, respectively. With guidelines that do not aptly account for parenting time, the father must pay $\$ 12,103$ in child support so that he has $\$ 42,000-\$ 12,103=\$ 29,897$ in disposable income, while the mother ends up with $\$ 30,000+\$ 12,103=\$ 42,103$. By reversing the incomes and increasing the difference, child support is 'starving' the children in one home to 'feed' them in the other.

Mississippi: A weekend father has two daughters with two different mothers. The mother of the older daughter has $\$ 80,000$ in net income, while the father and the other mother each has $\$ 40,000$. The higherearning mother receives $\$ 5,600$ in child support from the father, while he only pays the lower-earning mother $\$ 4,816$. Here, child support exacerbates the already large financial disparity between the two sisters.

New Jersey: Two siblings spend 183 days per year with father and 182 days with mother, with net incomes of $\$ 55,000$ and $\$ 45,000$, respectively. The lower-income mother pays the higher-income father $\$ 1,092$ in child support.

Minnesota: A father makes $\$ 75,000$ and mother $\$ 25,000$. Their two children spend 275 overnights with their father (75\%) and 90 with their mother (25\%). With salaries and time allocation in identical proportions, the mother must nevertheless pay $\$ 4,490$ to the father. With roughly $16 \%$ and $25 \%$ tax rates, the mother has $\$ 16,510$ in disposable income while the father has almost four times as much at $\$ 60,740$. [18]

Pennsylvania: A single father and a re-married mother have net incomes of $\$ 39,700$ and $\$ 60,300$, respectively. During the school year, their two children live every other week with each parent while they spend their $2 \frac{1}{2}$ month-long summer vacation (75 days) with their mother. Since $75+(365-$ $75) / 2=220=60.3 \%$, the income and parenting time proportions are the same, but the father pays $\$ 8,771$ in child support, leaving him with a disposable income of $\$ 30,929$, while the mother has $\$ 69,071$ plus whatever her new husband makes. 
Georgia: A never-married father has three children with three different mothers - a surprisingly common situation [19]. The mothers have no other children. All four parents each make $\$ 26,000$. Each of the children spends every other weekend plus some holidays and summer weeks with their father, for a total of 92 days. The father pays a total of $\$ 12,480$ in child support to the three mothers. With approximately $17 \%$ in taxes, each mother with one child for $365-92=273$ child-days has more than $\$ 25,000$ in disposable income while the father with $3 * 92=276$ child-days has only $\$ 9,100$. Unable to feed himself and his children, the father may be forced out of their lives or to default on payments and face jail.

Idaho: Idaho has a cliff effect [20] where child support jumps at $25 \%$ parenting time. Suppose a father has custody of two children that spend every other weekend and some holidays and vacation weeks with their mother for a total of 91 days. Both parents make $\$ 50,000$. The mother also wants them every other nonvacation Thursday, but the father refuses as it would decrease the child support received from $\$ 9,250$ to $\$ 5,208$. This sharp change amounts to a difference of $(\$ 9,250-\$ 5,208) / 23=\$ 176$ for each Thursday evening.

New Hampshire: A custodial father and non-custodial mother have one daughter, with each parent making $\$ 50,000$. The marginal cost for the child's health insurance is $\$ 1000$ on each parent's plan. If the mother carries it, she pays the $\$ 1,000$ plus $\$ 8,015$ in child support. If the father carries it, the mother must instead pay $\$ 8,235$ in child support, with the mother saving $\$ 780$, while the extra $\$ 220$ in child support only covers a fraction of the father's additional health insurance cost. Hence, the parent who carries the insurance is penalized by the guidelines; and health insurance may become a financial conflict rather than a financially neutral medical decision.

Rhode Island: With two children, the father and mother make $\$ 20,000$ and $\$ 40,000$, respectively. The state assigns total child expenditures to be $\$ 15,480$. With sole custody, parents contribute proportionally to income, with either $\$ 10,320$ from the mother or $\$ 5,160$ from the father in child support. With $50 / 50$ shared parenting, the mother pays $\$ 5,160$. Assuming that the state still wants contributions to be proportional to income, back calculations reveal that the assigned child expenditures are now $\$ 30,960$, with the mother's contribution at $\$ 30,960 / 2+\$ 5,160=\$ 20,640$ versus father's $\$ 30,960 / 2-\$ 5,160=\$ 10,320$. With a combined $16 \%$ tax rate, the state implicitly assigns $\$ 30,960 / 2=\$ 15,480$ as the expenses for each child and $(\$ 60,000 * 84 \%-\$ 30,960) / 2=\$ 9,720$ for each parent. Presumably unintentionally, the state implicitly assumes that children have considerably higher living expenditures than adults.

Utah: A non-custodial father has two daughters with the same mother, while his non-custodial neighbor has two sons with two different mothers. All five parents make $\$ 50,000$. If there had been no child support, the boys would be financially better off since the girls must share resources with a sister. Despite this, the boys' father pays $\$ 10,762$ in child support while the girls' father only pays $\$ 8,724$. A similar situation has been described in Texas [3].

To illustrate ten design issues, we devised ten simple hypothetical scenarios, keeping other variables similar or at zero. More complex scenarios can give more extreme results, and multiple design issues may pile up on the same family. . $[2,18]$.

While the exact scenarios and numbers differ, most of these design issues are present in multiple state guidelines. The Georgia, Minnesota, and Utah type issues are shared by all the ten randomly selected states; the Mississippi design issue by all except New Jersey and Pennsylvania; the Pennsy/vania scenario by Connecticut, Minnesota, New Hampshire, Rhode Island, and Utah; the New Hampshire health 
insurance problem by Connecticut and Rhode Island; the Idaho cliff issue by New Jersey, Pennsylvania, and Rhode Island, but at different cut-offs. The Connecticut income reversal can also occur in New Jersey due to a different design issue.

Since the child support formulas in 10 out of 10 states have design issues that produce what are presumably unintentional results, the point estimate from this random survey predicts that all 50 states have such design issues (95\% confidence interval: $37-50$ ).

\section{Child Support Framework and Subjective Norms}

Either explicitly or implicitly, all state child support guidelines determine the answers to the following three questions through the child support guidelines they use [20]:

- How much of total parental income is allocated to expenditures on child(ren)?

- What proportion of those expenditures does each parent contribute, given the income of each?

- What proportion of those expenditures is allocated to each parent, given the parenting schedule?

These are normative questions that the public and their legislators should decide explicitly. Other aspects of child support calculations reflect basic axioms to ensure that the normative goals are achieved and that children can be adequately cared for by both parents. Specifying formulas that meet these axioms is a mathematical/technical problem. It is like building a bridge. Politicians decide the location, type, size, and capacity, while engineers ensure accurate technical calculations to avoid a collapsing bridge.

\subsection{Child Support Obligation}

All states - either implicitly or explicitly - assign a basic child support obligation (BCSO), the combined child-rearing expenditures incurred by both parents. Note that this is not the amounts actually spent by parents but the normative amounts that the guidelines assign for child expenditures; parental spending on their children can diverge up or down from these obligations and often do. The BCSO varies between states. While the literature has identified problems in specifying the BCSO $[2,18]$, we take it as a given in this paper. The amount is not responsible for any of the surprising outcomes in the examples above.

In all ten states, the BCSO naturally increases with more income and more children. As a percentage of income, it typically decreases with increasing income, but for some income ranges in Minnesota, the BCSO percentage increases with increasing income. Cancian and Constanzo show how this creates a situation where a parent would pay less child support if the custodial parent had less income [17]. For example, a non-custodial Minnesota father making $\$ 21,000$ pays $\$ 4,620$ in child support if the mother has no income but $\$ 5,448$ if she makes $\$ 3,000$.

\subsection{Parental Contributions}

Contributions ( $C_{1}$ and $C_{2}$, with $C_{1}+C_{2}=B C S O$ ) refer to how much each parent should contribute to the child support obligation, as the total of in-kind expenditures plus child support to the other parent.

Let $f(x)=C_{1} /\left(C_{1}+C_{2}\right)$ be the percent contribution of the parent that makes $x \%=I_{1} /\left(I_{1}+I_{2}\right)$ of the combined income. We impose the following logical constraints on this function. 
(A) $f(0 \%)=0 \%$ and $f(100 \%)=100 \%$, since a person with zero income cannot contribute anything.

(B) $f(x)=100 \%-f(100 \%-x)$ for all $x \in[0 \%, 100 \%]$. This ensures that it does not matter which parent is assigned as \#1 or \#2, and both parents are treated symmetrically.

(C) $f(x)$ is an increasing function with respect to $x$. This constraint ensures that a parent would not contribute less if their proportion of the combined income is greater.

For sole custody, no health insurance, and most income ranges, all ten randomly selected states divide the BCSO in proportion to income $\left(I_{k}\right)$, which means that $f(x)=x$ and $C_{1} /\left(C_{1}+C_{2}\right)=I_{1} /\left(I_{1}+I_{2}\right)$. This assignment fulfills all criteria (A) to (C).

The contributions do not have to be proportional, though, and we consider other functions below. Wisconsin, for instance, divides the BCSO according to a partially regressive scheme; high-income parents contribute a lower percentage of their income than middle-income co-parents. Alternatively, as with progressive taxes, higher-income parents could contribute a larger proportion of their income. At the extreme, the high earner could contribute whatever it takes to equalize the funds available for parental expenditures. Pennsylvania does this for some 50/50 shared parenting situations. For example, with three children and net incomes of $\$ 38,000$ and $\$ 22,000$, the higher-earning parent pays $\$ 8,000$ in child support so that both families have $\$ 30,000$ in disposable income.

\subsection{Parental Allocations}

Both parents typically have some in-kind child expenditures [21]. Based on the parenting percentages $\left(T_{1}+T_{2}=1\right)$, where $T_{1}$ and $T_{2}$ are the fraction of time the children spend with parent 1 and parent 2 respectively, how much of the $\mathrm{BCSO}$ should be allocated $\left(A_{1}+A_{2}=B C S O\right)$ to each parent? We propose two axioms that the child support framework we derive will satisfy:

(D) Unless there are non-residential costs such as health insurance, if the parenting proportion is $T_{1}=0 \%$, then $A_{1}=0 \%$, if $T_{1}=T_{2}=50 \%$, then $A_{1}=A_{2}=50 \%$, and if $T_{1}=100 \%$, then $A_{1}=100 \%$. This constraint ensures that a parent who spends no time with their children receives no allocation from the $\mathrm{BCSO}$ and that if children spend half their time with each parent, each parent receives an equal portion of the BCSO.

(E) If the parenting proportion, $T_{1}$, increases, $A_{1} / B S C O$ should increase as well. That is, a larger proportion of the BSCO should be allocated to a parent as the parenting time increases.

The BCSO can be divided into variable costs (V), fixed costs (F), and reserved expenditures (R), with $\mathrm{BCSO}=\mathrm{V}+\mathrm{F}+\mathrm{R}$. Variable costs include items such as expenditures on food for the children, which are roughly proportional to parenting time. Fixed costs, such as beds for the children, are the same irrespective of parenting time. How to divide the BSCO into these three components is a normative question. The following formulas work as long as all three values are non-negative.

There are also reserved expenditures such as health insurance that the court assigns responsibility to one parent $\left(R_{1}+R_{2}=R\right)$. While less common, other examples include court orders that a non-custodial mother is responsible for the purchase of all clothing or a non-custodial father is responsible for the purchase of all school supplies. Orders of such in-kind contributions by a non-custodial parent can contribute to parent-child bonding [22].

All ten states account for parenting time in some manner. Only New Jersey uses a mix of variable, fixed, and reserved costs, but not in a way that avoids the types of outcomes in the example above. 


\section{Child Support Formulas for Different Contribution and Allocation Norms}

Let $S_{12}$ be the child support from parent \#1 to parent \#2. By definition, the allocation is equal to contribution minus child support, so that $A_{1}=C_{1}-S_{12}$ and $S_{12}=C_{1}-A_{1}$. When $S_{12}$ is negative, it is parent $\# 2$ that is paying child support. Since $A_{2}=C_{2}+S_{12}$, and $S_{12}=A_{2}-C_{2}=-\left(C_{2}-A_{2}\right)$, the formula is symmetric, and it does not matter which parent is assigned as \#1, ensuring internal consistency.

\subsection{Doubly Proportional Norm}

One potential norm is that parents contribute in proportion to income, with $f(x)=x$, while they are allocated funds in proportion to parenting time. Absent health insurance, this means that $C_{1} /\left(C_{1}+C_{2}\right)=I_{1} /\left(I_{1}+I_{2}\right), V=B C S O, F=R_{1}=R_{2}=0$ and $A_{1} /\left(A_{1}+A_{2}\right)=T_{1} /\left(T_{1}+T_{2}\right)=T_{1}$. It is then straightforward algebra to calculate that $C_{1}=(B C S O) * C_{1} / B C S O=B C S O * C_{1} /\left(C_{1}+C_{2}\right)=B C S O * I_{1} /\left(I_{1}+I_{2}\right)$ and $A_{1}=B C S O * T_{1}$, so that the formula for the amount of child support is

$$
\mathrm{S}_{12}=\mathrm{C}_{1}-\mathrm{A}_{1}=\operatorname{BCSO}\left(\frac{\mathrm{I}_{1}}{\mathrm{I}_{1}+\mathrm{I}_{2}}-\mathrm{T}_{1}\right)
$$

\subsection{Proportional Contribution Norm with Variable, Fixed, and Reserved Cost Allocations}

When the basic child support obligation is divided into variable, fixed, and reserved costs, one may allocate the variable costs in proportion to parenting time, the fixed costs equally between the parents and the reserved costs according to the court order.

The allocations to the two parents are then $A_{1}=V^{*} T_{1}+F / 2+R_{1}$ and $A_{2}=V^{*} T_{2}+F / 2+R_{2}$, respectively. The child support formula is:

$$
\mathrm{S}_{12}=\mathrm{C}_{1}-\mathrm{A}_{1}=\mathrm{BCSO} * \frac{\mathrm{I}_{1}}{\mathrm{I}_{1}+\mathrm{I}_{2}}-\left(V T_{1}+\frac{\mathrm{F}}{2}+\mathrm{R}_{1}\right)
$$

\subsection{Split Custody}

With split custody, one or more children live primarily with one parent while their siblings live primarily with the other parent. More generally, with $\mathrm{K}$ total kids, let $\mathrm{T}_{\mathrm{i}}(k)$ be the percent of the time that child $k$

lives with parent i. With the same norms as in 4.2, the allocations are then $A_{1}=\sum_{k} \frac{V}{K} T_{1}(k)+\frac{F}{2}+R_{1}$ and $A_{2}=\sum_{k} \frac{V}{K} T_{2}(k)+\frac{F}{2}+R_{2}$ respectively, and the child support formula is

$$
\mathrm{S}_{12}=\mathrm{C}_{1}-\mathrm{A}_{1}=\mathrm{BCSO} \frac{\mathrm{I}_{1}}{\mathrm{I}_{1}+\mathrm{I}_{2}}-\left(\sum_{\mathrm{k}} \frac{\mathrm{V}}{\mathrm{K}} \mathrm{T}_{1}(\mathrm{k})+\frac{\mathrm{F}}{2}+\mathrm{R}_{1}\right)
$$

This formula can also be used for the doubly proportional norm by setting $F=0$ and $R_{1}=0$.

\subsection{Non-Proportional Contributions}


Legislators may choose a policy norm where contributions are not proportional to parental income, similar to progressive or regressive income taxes not set proportionally to income. The formulas can be adjusted to account for that. The only $3^{\text {rd }}$ degree or lower polynomial function that fulfills criteria (A), (B), and $(C)$ above is

$$
f(x)=a x^{3}-\frac{3 a}{2} x^{2}+\left(1+\frac{a}{2}\right) x
$$

with $a \geq-2$ and $a \leq 4$, where $a$ is a subjective tuning parameter. With $a<0$, the higher-income parent contributes a higher proportion of their income. When $a>0$, the lower-income parent contributes a higher proportion. When $a=0, f(x)=x$, which is the proportional contribution norm.

To calculate child support using non-proportional contributions, simply replace $I_{1} /\left(I_{1}+I_{2}\right)$ with $f\left(I_{1} /\left(I_{1}+I_{2}\right)\right)$ in equations (1) to (3). Table 1 shows how $\mathrm{f}(\mathrm{x})$ varies for different values of $a$.

Table 1: Percent parental contribution for different income proportions and values of the tuning parameter $a$.

\begin{tabular}{lrrlllllllll} 
& \multicolumn{10}{c}{ Proportion of Combined Income } \\
$\mathbf{a =}$ & $\mathbf{x = 0}$ & $\mathbf{1 0 \%}$ & $\mathbf{2 0 \%}$ & $\mathbf{3 0 \%}$ & $\mathbf{4 0 \%}$ & $\mathbf{5 0 \%}$ & $\mathbf{6 0 \%}$ & $\mathbf{7 0 \%}$ & $\mathbf{8 0 \%}$ & $\mathbf{9 0 \%}$ & $\mathbf{1 0 0 \%}$ \\
\hline $\mathbf{- 2}$ & $0 \%$ & $3 \%$ & $10 \%$ & $22 \%$ & $35 \%$ & $50 \%$ & $65 \%$ & $78 \%$ & $90 \%$ & $97 \%$ & $100 \%$ \\
$\mathbf{- 1}$ & $0 \%$ & $6 \%$ & $15 \%$ & $26 \%$ & $38 \%$ & $50 \%$ & $62 \%$ & $74 \%$ & $85 \%$ & $94 \%$ & $100 \%$ \\
$\mathbf{0}$ & $0 \%$ & $10 \%$ & $20 \%$ & $30 \%$ & $40 \%$ & $50 \%$ & $60 \%$ & $70 \%$ & $80 \%$ & $90 \%$ & $100 \%$ \\
$\mathbf{2}$ & $0 \%$ & $17 \%$ & $30 \%$ & $38 \%$ & $45 \%$ & $50 \%$ & $55 \%$ & $62 \%$ & $70 \%$ & $83 \%$ & $100 \%$ \\
$\mathbf{4}$ & $0 \%$ & $24 \%$ & $39 \%$ & $47 \%$ & $50 \%$ & $50 \%$ & $50 \%$ & $53 \%$ & $61 \%$ & $76 \%$ & $100 \%$ \\
\hline
\end{tabular}

Two notes of caution: (i) If a regressive allocation is chosen, such as in Wisconsin, a high value of the parameter $a$ will result in a situation where a poor parent must contribute an extraordinarily high proportion of their income. In the extreme, the contribution can even exceed their income. For example, if $I_{1}=\$ 1,000, I_{2}=\$ 99,000, B S C O=\$ 40,000$, and $a=4$, then $C_{1}=\$ 1,176$. (ii) While never true for any of the ten states, if $\mathrm{BSCO} /\left(\mathrm{I}_{1}+\mathrm{I}_{2}\right)>2 / 3$, then a progressive allocation with $\mathrm{a}=-2$ can result in the strange situation where $I_{1}-C_{1}>I_{2}-C_{2}$ even when $I_{1}<I_{2}$. That is, the parent with the higher income has less parental allocation than the lower income parent.

\subsection{Absentee Parents}

Absentee parents $\left(T_{1}=0\right)$ have neither variable nor fixed expenses. In this case, a coherent specification of the total child support obligation is $\mathrm{V}+\mathrm{F} / 2+\mathrm{R}=\mathrm{BSCO}-\mathrm{F} / 2$ instead of BSCO, and the absentee parent's allocation is only $R_{1}$. With the norms of Section 4.2 , the child support amount is then

$$
\mathrm{S}_{12}=\mathrm{C}_{1}-\mathrm{A}_{1}=\left(B C S O-\frac{F}{2}\right) \frac{\mathrm{I}_{1}}{\mathrm{I}_{1}+\mathrm{I}_{2}}-\mathrm{R}_{1}
$$

When $\mathrm{F}>0$, this gives the $100 \%$ absentee parent a financial break and a financial incentive never to see their child. To avoid rewarding "dead-beat" moms and dads, formula (2) could be used instead of (4) unless the absence is forced or involuntary due to, e.g., incarceration or parental alienation. 


\subsection{Non-Insured Medical Expenses}

Suppose that uninsured medical expenses, such as medications and eyeglasses, are included when assigning the BCSO. It is then natural to divide them according to the allocation formula, with parent \#1 paying $100 * A_{1} / B C S O$ percent. If these expenses are not included in the $B C S O$ assignment, it is natural to apportion contributions as $C_{1} /\left(C_{1}+C_{2}\right)$ and $C_{2} /\left(C_{1}+C_{2}\right)$ for parents 1 and 2 , respectively. Such shares ensure internal consistency and fulfillment of the subjective norms chosen.

Some children have extreme special needs due to autism, spastic paraplegia, or Down's syndrome, for example. Accounting for this involves a simple modification to the above formulas. Let $D>1$ be a diseasespecific constant that reflects the extra expenditure for caring for a special needs child, where the exact amount is a subjective policy decision. In the formulas, one may then simply multiply the BCSO by D and replace $\mathrm{BCSO}$ with $\mathrm{BCSO}{ }^{*} \mathrm{D}$.

\section{Non-Joint Children}

It is common for parents to have responsibility for children not jointly held by the other parent $[3,8]$. For example, for $31 \%$ of the parents in the Wisconsin child support administration system, either the mother or the father has additional children with a different person [19]. The examples above from Mississippi, Georgia, and Utah are situations with non-joint children, but all ten state guidelines have these types of design issues with similar results.

\subsection{Subjective Axioms/Norms}

We present four axioms or norms for calculating child support amounts in the presence of non-joint children:

(F) The birth order of the children does not matter.

(G) A parent shall either contribute equally to all their children or more to children with a financially weaker co-parent.

(H) Parental contributions should only be for their own children and not depend on the ex-spouse's other children.

(I) Child support should only depend on the income of the child's two parents, not on the income of a parent's ex-partner.

Note that $(\mathrm{G})$ and $(\mathrm{H})$ refer to parental contributions rather than child support, which also depends on parenting schedules and the co-parents' contribution. Seven of the ten states violate all four criteria; Mississippi the first two; New Jersey the last three; and Pennsylvania the last one. Other approaches [19] also fail to fulfill these norms.

From a parent's perspective, one could argue that birth order should matter. The co-parent of an older child had no say in the birth of the younger one, while the co-parent of a younger child knew about the existing financial obligation for the older child. From the perspective of the children's best interest, neither child had a say on the matter, so (F) may then be a reasonable norm. 
In (I), the income of a current spouse is a different matter, which instead could be handled as part of the income definition. It is curious to note that all ten state guidelines ignore the income of current spouses, but in most states, the amount of child support may depend on the income of the previous ex of an exspouse.

\subsection{Child Support Formulas for Non-Joint Children}

When there are non-joint children, first directly calculate each parents' contribution for each joint child and then add them to get the total BCSO for each parent pair. This total can then be divided according to the allocation formulas above.

Let $K_{1}$ and $K_{2}$ be the total number of children of parents $\# 1$ and $\# 2$, respectively, while $K_{12}$ is their number of joint children. Let $\mathrm{BCSO}\left(\mathrm{K}_{1}, \mathrm{l}_{1}+\mathrm{I}_{2}\right)$ be the standard basic child support obligation for $\mathrm{K}_{1}$ children when the combined income is $I_{1}+l_{2}$. For each joint child, parent \#1 would then contribute $\mathrm{BCSO}\left(\mathrm{K}_{1}, \mathrm{I}_{1}+\mathrm{I}_{2}\right) *\left[\mathrm{f}\left(\mathrm{I}_{1} /\left(\mathrm{I}_{1}+\mathrm{I}_{2}\right)\right)\right] / \mathrm{K}_{1}$. This amount is simply the standard BCSO times the parent's contribution percentage divided by the parent's total number of children. The total BCSO for all their joint children is $\mathrm{K}_{12} *\left[\mathrm{BCSO}\left(\mathrm{K}_{1}, \mathrm{I}_{1}+\mathrm{I}_{2}\right) *\left[\mathrm{f}\left(\mathrm{I}_{1} /\left(\mathrm{I}_{1}+\mathrm{I}_{2}\right)\right)\right] / \mathrm{K}_{1}+\mathrm{BCSO}\left(\mathrm{K}_{2}, \mathrm{I}_{1}+\mathrm{I}_{2}\right) *\left[\mathrm{f}\left(\mathrm{I}_{2} /\left(\mathrm{I}_{1}+\mathrm{I}_{2}\right)\right)\right] / \mathrm{K}_{2}\right]$. For the special case when all children are joint, the formula reverts to the standard one, ensuring internal consistency.

With this formula, it is evident that $(F),(H)$, and $(I)$ hold. For $(G)$ to hold, BCSO divided by income must be non-increasing with increasing income.

Example: An Idaho mother making $\$ 60,000$ has one child with father $\# 1$, who makes $\$ 90,000$, and two younger children with father $\# 2$, who makes $\$ 40,000$. Neither father has additional children.

For the oldest child, the standard $\mathrm{BCSO}$ are $\mathrm{BCSO}(3, \$ 150,000)=\$ 27,600$ and $\mathrm{BCSO}(1, \$ 150,000)=\$ 15,100$. With $60,000 /(60,000+90,000)=40 \%$ of the income and proportional contributions, mother contributes $\$ 27,600 * 40 \% / 3=\$ 3,680$, while father contributes $\$ 15,100 * 60 \%=\$ 9,060$.

For the younger children $\mathrm{BCSO}(3, \$ 100,000)=\$ 22,000$ and $\mathrm{BCSO}(2, \$ 100,000)=\$ 18,500$. With $60 \%$ of the income, the mother contributes $\$ 22,000 * 60 \% / 3=\$ 4,400$ for each child, while the father contributes $\$ 18,500 * 40 \% / 2=\$ 3,700$. Note that the mother contributes less for her oldest child, who has a higher income father.

If all children always live with their mother, she receives $\$ 9,060$ from father $\# 1$ and $2 * \$ 3,700=\$ 7,400$ from father \#2. If they always live with their fathers, father \#1 receives $\$ 3,680$ while father \#2 receives $2 * \$ 4,400=\$ 8,800$. If all children have $50 / 50$ shared parenting, mother receives $C_{1}-A_{1}=C_{1}-B C S O / 2=\$ 9,060$ $(\$ 9,060+\$ 3,680) / 2=\$ 2,690$ from father $\# 1$ and pays $\$ 8,800-(\$ 8,800+\$ 7,400) / 2=\$ 700$ to father $\# 2$.

\section{Revisiting the Ten Examples}

Without changing the state-assigned BCSOs, our framework produces the following results for the ten examples described in Section 2. With doubly proportional norms:

- The $50 / 50$ custodial Connecticut father pays $\$ 1,729$ rather than $\$ 12,103$ in child support.

- The low-income Mississippi mother receives $\$ 1,120$ more than the high-income mother, not $\$ 784$ less.

- The New Jersey mother receives $\$ 483$ rather than pays $\$ 1,027$ in child support. 
- The low-income single parents in Minnesota and Pennsylvania do not pay any child support to their higher-earning ex-spouses.

- The three-kid single father in Georgia has $\$ 19,229$ rather than $\$ 9,100$ in disposable income.

- Rhode Island no longer assumes that children have more expenditures than adults.

- The finances of the parents in New Hampshire do not depend on who carries the health insurance.

- In Idaho, the difference in child support is $\$ 1,166$ rather than $\$ 4,033$.

- The Utah father with the girls pays $\$ 506$ more rather than $\$ 2,038$ less when compared to his neighbor.

\section{Discussion}

Current formulas for child support amounts can produce surprising and presumably unintended child support amounts. This paper outlines a consistent framework for calculating child support. It requires the input of subjective norms explicitly set by a legislature, and it ensures that the results are in accord with the specified norms.

This paper does not propose any specific child support amounts. Nor does it suggest what the BSCO should be or how much each parent should contribute to it or be allocated from it. Those are subjective normative decisions that state legislatures must make. Instead, this paper provides a logical-mathematical framework to transform subjective norms to child support amounts under a wide variety of scenarios. Calculating the division of child support payments according to this framework automatically avoids violating a set of basic axioms that we have specified. The framework that we outline could serve as an input to modifying current child support allocations to resolve some of the features that we have identified in current structures.

Unlike the Internal Revenue Service, which determines taxes based on actual income, child support is based on court-assigned income that can be less than actual income or more than achievable income [4, 9]. The formulas we propose in this paper can be used no matter how the income amounts are determined. When income or family size changes, states have a cumbersome court process to change to a more suitable child support payment. With a logically coherent framework, that process can be made more efficient without costly new court appearances.

Epidemiologic research shows that children do best with equal or near-equal time shared parenting with respect to their physical, mental, and behavioral health outcomes. [23] Despite this, parents receive a financial windfall for having sole custody versus shared parenting in most states. Similarly, in all ten states we analyze, child support is the same or similar for weekend and absentee parents, financially rewarding the latter as they have no in-kind expenses. Hence, many of the current guidelines incentivize parenting schedules that are not in children's best interest. 


\section{References}

[1] T. Grall, "Custodial mothers and fathers and their child support: 2015," United States Census Bureau, Washington DC, 2018.

[2] W. S. Comanor, Ed., The law and economics of child support payments, Edward Elgar Publishing, 2004.

[3] K. Edin, "Child Support in the Age of Complex Families," Issues in Science and Technology, vol. 34, pp. 38-45, 2018.

[4] V. Turesky, "Reforming Child Support to Improve Outcomes for Children and Families," The Abell Foundation, Baltimore, MD, 2019.

[5] E. Claessens and D. Mortelmans, "Challenges for child support schemes: Accounting for shared care and complex families," Journal of European Social Policy, vol. 28, pp. 211-223, 2018.

[6] Office of Child Support Enforcement, "Preliminary Report F.Y. 2018," United States Department of Health and Human Services, Washington DC, 2018.

[7] L. A. Hall, L. L. Passarella and C. E. Born, "Who pays child support? Non-custodial parents' payment compliance," University of Maryland School of Social Work, Baltimore, MD, 2014.

[8] E. Cozzolino, "Public Assistance, Relationship Context, and Jail for Child Support Debt," Socius: Sociological Research for a Dynamic World, vol. 4, pp. 1-25, 2018.

[9] E. G. Patterson, "Civil Contempt and the Indigent Child Support Obligor: The Silent Return of Debtor's Prison," Cornell Journal of Law and Public Policy, vol. 18, pp. 95-141, 2008.

[10] H. Um, "The Role of Child Support Debt on the Development of Mental Health Problems among Nonresident Fathers," Princeton University, Woodrow Wilson School of Public and International Affairs, Center for Research on Child Wellbeing, 2019.

[11] H. Meltzer, P. Bebbington, T. Brugha, R. Jenkins, S. McManus and M. S. Dennis, "Personal debt and suicidal ideation," Psychological Medicine, vol. 41, pp. 771-778, 2011.

[12] L. M. Berger and J. N. Houle, "Parental Debt and Children's Socioemotional Well-being," Pediatrics, vol. 37, p. e20153059, 2016.

[13] K. J. Turner and M. R. Waller, "Indebted relationships: Child support arrears and nonresident fathers' involvement with children," Journal of Marriage and Family, vol. 79, pp. 24-43, 2017.

[14] N. D. Zatz, "A New Peonage?: Pay, Work, or Go to Jail in Contemporary Child Support Enforcement and Beyond," Seattle University Law Review, vol. 39, pp. 927-955, 2016.

[15] T. L. Brito, "Fathers Behind Bars: Rethinking Child Support Policy Toward Low-Income Noncustodial Fathers and their Families," Journal of Gender, Race and Justice, p. 417, 2012. 
[16] E. Durchholz, "Tulsa child support enforcement system jails parents for living in poverty," Tulsa World, 2692019.

[17] M. Cancian and M. A. Costanzo, "Comparing income-shares and percentage-of-income child support guidelines," Children and Youth Services Review, vol. 96, pp. 451-462, 2019.

[18] R. M. Rogers and D. J. Bieniewicz, "Child support guidelines: Underlying methodologies, assumptions, and the impact on standards of living," in The Law and Economics of Child Support Payments, Northampton, MA, USA, Edward Elgar, 2004, pp. 60-90.

[19] M. Cancian and D. R. Meyer, "Who owes what to whom? Child support policy given multiplepartner fertility," Social Service Review, vol. 85, pp. 587-617, 2011.

[20] D. Bieniewicz, "Child Support Guideline Developed by Children's Rights Council," in Child Support Guidelines: The Next Generation, Washington DC, United States Department of Health and Human Services, 1994, pp. 104-125.

[21] W. V. Fabricius and S. L. Braver, "Non-Child Support Expenditures on Children by Nonresidential Divorced Fathers," Family Court Review, vol. 41, pp. 321-336, 2003.

[22] M. Ryznar, "In-Kind Child Support," Journal of the American Academy of Matrimonial Lawyers, vol. 29, pp. 351-376, 2017.

[23] L. Nielsen, “Joint Versus Sole Physical Custody: Children's Outcomes Independent of Parent-Child Relationships, Income, and Conflict in 60 Studies," Journal of Divorce and Remarriage, vol. 59, pp. 247-281, 2018. 


\section{Supplementary Material}

All calculations used the written child support guidelines referenced below. Some states also provide an online child support calculator. Amounts may differ slightly different due to round-off errors.

Connecticut: State of Connecticut, Commission for Child Support Guidelines, Child Support and Arrearage Guidelines, Effective July 1, 2015:

https://www.jud.ct.gov/Publications/ChildSupport/CSguidelines.pdf

Georgia: State of Georgia, Guide to Implementation of the New State Child Support Guidelines, Prepared by the Staff of the Child Support Commission, January 2007.

https://georgiacourts.gov/wp-content/uploads/2019/07/imp guide optim.pdf

Calculator: https://www.georgiacourts.gov/csc/

Idaho: The Idaho Child Support Guidelines, Rule 6(c)(6) of the Idaho Rules of Civil Procedure, 2012. https://isc.idaho.gov/files/ICSG-July 1 2012.pdf

Minnesota: Minnesota Statutes 2018, 518A.26-518A.39

https://www.revisor.mn.gov/statutes/cite/518A.

Calculator: https://childsupportcalculator.dhs.state.mn.us/

Mississippi: Mississippi Code Annotated, §§ 43-19-101 to 43-19-103, Child Support Award Guidelines https://law.justia.com/codes/mississippi/2016/title-43/chapter-19/child-support-award-guidelines/

New Jersey: Rules Governing the Courts of the State of New Jersey, Rule 5:6A. Child Support Guidelines https://www.njcourts.gov/attorneys/assets/rules/r5-6a.pdf

Calculator: https://www.njchildsupport.org/resources-forms/other-resources/guidelines-

calculator/guidelines-calculator.aspx (Note: The calculator uses gross income while the guidelines are based on net income.)

New Hampshire: State of New Hampshire, Department of Health and Human Services, Bureau of Child Support Services, Child Support Guidelines, 2019.

https://www.dhhs.nh.gov/dcss/documents/dcss-guide-book.pdf

Calculator: https://www.dhhs.nh.gov/dcss/calculator.htm

Pennsylvania: Pennsylvania Code, 1910.16-1 to 1910.16-7

https://www.pacode.com/secure/data/231/chapter1910/s1910.16-1.html

Calculator: https://www.humanservices.state.pa.us/CSWS/

Rhode Island: Rhode Island Family Court, Administrative Orders 2017-01, 2018-01 and 2018-02.

http://www.cse.ri.gov/guidelines/index.php

Utah: Utah Judicial Code, Chapter 12, Utah Child Support Act

https://le.utah.gov/xcode/Title78B/Chapter12/78B-12.html

Calculator: https://orscsc.dhs.utah.gov/orscscapp-hs/orscscweb/

Wisconsin: Wisconsin Administrative Code and Register, Department of Children and Families, Chapter DCF 150, Child Support Percentage of Income Standard, June 2019.

https://docs.legis.wisconsin.gov/code/admin code/dcf/101 199/150.pdf 